etymology based on the Slavic stem * chmur-, demonstrating that semantically the two words match perfectly, and dissolving the phonological doubts that may arise at first sight.

Keywords: komor, komoly, etymology, Slavic, Turkic, loanwords.

GALAC ÁDÁM

Eötvös Loránd Tudományegyetem

\title{
A bagoly és társai
}

BALÁZS JÁNOS Az etimológia elmélete és módszere című nemzetközi konferenciakötetben (1976) fejti ki a jelen témaválasztás szempontjából fontos nézetét A belső keletkezésű szavak etimologizálásának problémáiról címü cikkében. Megemlíti, hogy belső keletkezésünek tarthatjuk az olyan elemeit a szókészletnek, amelyek morfonológiai szerkezete összhangban áll a nyelvünk alaptípusaival. Söt további bizonyosságot nyerhet a szó eredete, ha a végén valószínüsíthető képzőelem áll. Így az ismeretlen eredetü magyar bogár szót illetően úgy nyilatkozik, hogy az -ár szóvégi deverbális névszóképzővel jött létre a búg hangutánzó igéből, és talán régebbi alakja, a bugár is ezt támasztja alá (BALÁzS 1976: 71-72). A TESz. az ismeretlen eredetű szóhoz annyit füz hozzá, hogy talán az $u$-s alakok eredetibbek (TESz. 1: 321; EWUng. 1: 116).

E gondolatok késztettek arra, hogy a búg igéhez tartozását próbáljam meg bizonyítani egy másik élölény nevének is. A kérdéses lexéma a bagoly madárnév, melynek régi és nyelvjárási alakjai között találni első szótagban o-t mutatókat is: bogój, bogaj, bogoj, bogoly (ÚMTsz. 1: 304). Figyelmet érdemelnek az 1389-es Bogul, 1395-ös és 1405 k.-i bagul alakok, ugyanis a TESz.-ben az ly-es alakok elsőbbségének lehetősége olvasható (TESz. 1: 217; EWUng. 1: 68). A hangutánzó háttér miatt mutathat háromféle zártságot a tő: búg, bogár, bagoly bogul; van példa hasonló megoszlást mutató változatokra más a hangutánzói eredetet mutató szavaknál is: mukkan, mókus, makog. Az -l záró hatása is szóba jöhet a bagoly példájában a második szótagi magánhangzót illetően, míg a bogár esetében az - $r$ nyújtóhatására is gyanakodhatunk, amellett, hogy az -r képzőn kívül az -ár/-ér képzőt is feltételezhetjük a második szótagban. A morfematikai elhomályosulással párhuzamosan a szóvégen álló - $l$ képző palatalizálódhatott, a töben pedig talán eredetibb az $o$, amelyből nyíltabbá válással alakult ki az $a$-s változat (a folyamatra 1. E. ABAFFY 2003: 329). Emellett talán az ómagyar adatokban érdemes gondolni a BENKÖ által javasolt olvasati alternatívára (BENKÖ 1980: 89-93), amely az [ä] és [a] hangok kettőssége okozta írásbeli jelölés eltolódását eredményezte. Így az $o$ jelölhette az [a]-t is, az $u$ pedig jelölhette (pl. a bogár esetében) az [o]-t is. A névadás indítéka a baglyokra jellemző tipikus hangadás lehetett, amely észlelése az újabb korokban a búgás felől a huhogásba tartott, de mindkettőben közös a mély hangtartomány kifejezése. A bagoly madárnév egyik lehetséges magyarázataként a hangutánzó szói eredetet a CzF.-ban is megtaláljuk (1: 378).

Ugyanakkor érdemes kitérni arra is, hogy a búg ige hangutánzó jellege további kérdések felvetéséhez is vezet. Bár a hangalak motiváltsága önmagában is okozhat szabálytalanabb viselkedést, de számolhatunk rendszerszerü fejlődésekkel is. Ilyen magyarázat lehet az, hogy a kétszeres nyíltabbá válással $(u>o>a$, 1. E. ABAFFY 2003: 330) kialakult változatok a nyelvérzék számára felfedezhető etimológiai kapcsolattól eltávolodtak: búg bogár 
bagoly. A különlegesebb viselkedésre utalhat, hogy palatoveláris párhuzamok is kialakulhattak: dong döng, gyúr gyür stb. - tehát hangutánzó alakpárok azonos nyelvállásfokon is létrejöhetnek. A búg palatális hangrendü párja viszont a bög lehet (sőt a bagoly keletkezésmódjára lehet példa a bögöly is), ezért feltételezhető egy eredetibb *bog vagy *bóg ige is.

Kicsit messzebbre vezet, de talán a bagzik ige korai előfordulásai és elsődleges jelentése (ti. 'párosodik') is ehhez a szótőhöz kapcsolódik, szemben a későbbi $k$-t mutató alakokkal. A két különböző szó (a búg és bak esetében *bag- 'búg' × bak : bakzik, 1. pl. kos : koslat) a nyelvérzékben a hasonló alaki felépítés és szemantikai tartalom alapján keveredhetett, ez (is) okozhatta a bakzik alakok megszületését. Lehetségesnek tartom, hogy a bagzik ige esetében szintén a hangadáson alapuló névadás mutatkozik meg, elég, ha csak a bőgő szarvasbikákra vagy kandúrokra gondolunk, de a pár megtalálása utáni folyamatok bizonyos körülményei is szintén a búg igéhez köthetik e szót.

\section{Hivatkozott irodalom}

E. ABAFFy ERZSÉBET 2003. Hangtörténet (ómagyar kor). In: KISS JENÖ - PUSZTAI FERENC szerk., Magyar nyelvtörténet. Osiris Kiadó, Budapest. 301-349.

BALÁZS JÁNOS 1976. A belső keletkezésű szavak etimologizálásának problémáiról. In: BENKŐ LORÁND - K. SAL ÉVA szerk., Az etimológia elmélete és módszere. Akadémiai Kiadó, Budapest. 68-73.

BENKŐ LORÁND 1980. Az Árpád-kor magyar nyelvü szövegemlékei. Akadémiai Kiadó, Budapest. CzF. = CZUCZOR GERGELY - FOGARASI JÁNOS, A magyar nyelv szótára 1-6. Emich / Athenaeum, Pest / Budapest, 1862-1874.

EWUng. = Etymologisches Wörterbuch des Ungarischen 1-2. Hrsg. BENKÖ, LORÁND. Akadémiai Kiadó, Budapest, 1993-1995.

TESz. = A magyar nyelv történeti-etimológiai szótára 1-3. Főszerk. BENKŐ LORÁND. Akadémiai Kiadó, Budapest, 1967-1976.

ÚMTsz. = Új magyar tájszótár 1-5. Főszerk. B. LÖRINCZY ÉvA. Akadémiai Kiadó, Budapest, 19792010.

NÉMETH DÁNIEL

Eötvös Loránd Tudományegyetem

\section{TUDOMÁNYTÖRTÉNET}

\section{Diszciplináris kölcsönhatások \\ Emlékezés a 90 éve született és 10 éve elhunyt Szabó Zoltánra}

A magyar nyelvtörténet, ezen belül az irodalmi nyelv története, a nyelvjárástan, a stilisztika és a szövegtan kiemelkedő tudósa, Szabó Zoltán professzor 90 éve született és 10 éve hunyt el. A kolozsvári egyetem magyar nyelvészeti tanszékének hosszú ideig vezetője, a Nyelv- és Irodalomtudományi Közlemények föszerkesztője. Sokoldalú és igen gazdag tudományos tevékenysége mellett igazi tanár volt, iskolateremtő. Számos tanítványa ma is módszeres tanításának hatása alatt végzi kutatómunkáját, tanít és nevel. Intézményte- 